\title{
Rare cause of massive gastrointestinal bleeding. A case of metastatic melanoma
}

\section{Rzadka przyczyna masywnego krwawienia z przewodu pokarmowego. Opis przypadku pacjentki z przerzutami czerniaka}

\author{
Krzysztof Dąbkowski ${ }^{1 凶}$, Karolina Michalska, Natalia Rusiniak-Rossińska1, Andrzej Białek1, \\ Katarzyna Kołaczyk², 3, Katarzyna Graca-Pakulska¹, Teresa Starzyńska1 \\ ${ }^{1}$ Pomorski Uniwersytet Medyczny w Szczecinie, Klinika Gastroenterologii, ul. Unii Lubelskiej 1, 71-252 Szczecin \\ Pomeranian Medical University in Szczecin, Department of Gastroenterology \\ ${ }^{2}$ Zachodniopomorskie Centrum Onkologii w Szczecinie, Zakład Radiologii, ul. Strzałowska 22, 71-730 Szczecin \\ West Pomeranian Oncology Center in Szczecin, Department of Radiology \\ ${ }^{3}$ Pomorski Uniwersytet Medyczny w Szczecinie, Zakład Diagnostyki Obrazowej i Radiologii Interwencyjnej, ul. Unii Lubelskiej 1, 71-252 Szczecin \\ Pomeranian Medical University in Szczecin, Department of Diagnostic Imaging and Interventional Radiology \\ $\triangle$ dabkowskikrzysztof@wp.pl
}

\section{ABSTRACT}

The case of a 76-year-old patient, with a history of melanoma admitted to the department of gastroenterology with symptoms of hypovolemic shock, caused by massive gastrointestinal bleeding. Clot-covered melanoma metastases were detected in both gastroduodenoscopy and colonoscopy. Gastrointestinal melanoma metastases are found in the majority of patients with advanced melanoma during autopsy; however, they are rarely detected in intravital studies and can be misdiagnosed as other benign lesions in endoscopy. In cases of patients with history of melanoma, metastases should be considered as the cause of non-specific abdominal symptoms, anemia, or bleeding from the gastrointestinal tract.

Keywords: melanoma; gastrointestinal hemorrhage; gastrointestinal metastases.

\begin{abstract}
ABSTRAKT
Przedstawiono przypadek 76-letniej pacjentki z czerniakiem skóry w wywiadzie, która została przyjęta do kliniki gastroenterologii z objawami wstrząsu hipowolemicznego, wtórnego do masywnego krwawienia z przewodu pokarmowego. Badania endoskopowe wykazały obecność pokrytych skrzepami zmian przerzutowych czerniaka, zarówno w żołądku, jak i w jelicie grubym. Przerzuty do przewodu pokarmowego
\end{abstract}

stwierdzane są w badaniach autopsyjnych u większości pacjentów z zaawansowanym czerniakiem, natomiast rzadko diagnozuje się je w badaniach endoskopowych. Powinny być brane pod uwagę jako przyczyna dolegliwości ze strony przewodu pokarmowego i krwawienia w przypadku pacjenta z czerniakiem w wywiadzie.

Słowa kluczowe: czerniak; krwawienie z przewodu pokarmowego; przerzuty do przewodu pokarmowego.

\section{CASE REPORT}

A 76-year-old female patient, with a history of metastatic melanoma, was admitted to the department of gastroenterology with symptoms of hypovolemic shock, secondary to gastrointestinal bleeding.

The diagnosis of metastatic melanoma was made 8 months before admission. The primary lesion was located on the skin of the left lumbar area. Initial CT scan revealed metastases to the axillary lymph nodes, adrenal cortex, spleen, and both lungs (Fig. 1 and 2). Immunotherapy treatment (nivolumab) was administered. For 6 months she had observed the presence of fresh blood in the stool and had suffered from anemia. A colonoscopy, performed one month before admission, discovered polypoid lesions in the ascending colon. The surgeons decided to perform right hemicolectomy. The histopathological examination was consistent with melanoma metastases. Following surgery, the bleeding stopped and the patient was disqualified from oncological treatment (ECOG performance score 4).

Unfortunately, one month later the patient was admitted to department with symptoms of massive gastrointestinal bleeding (fresh blood in stool). Colonoscopy and upper endoscopy showed numerous polypoid and tumor-like lesions, many of them clot-covered, in both the stomach and colon (Fig. 3, 4 and 5). Following blood transfusion and fluid therapy the patient improved and was discharged. After this time, he was twice hospitalized due to life-threatening anemia (total of 10 units of blood were transfused). The patient died 3 months after first hospital stay, due to bleeding. 


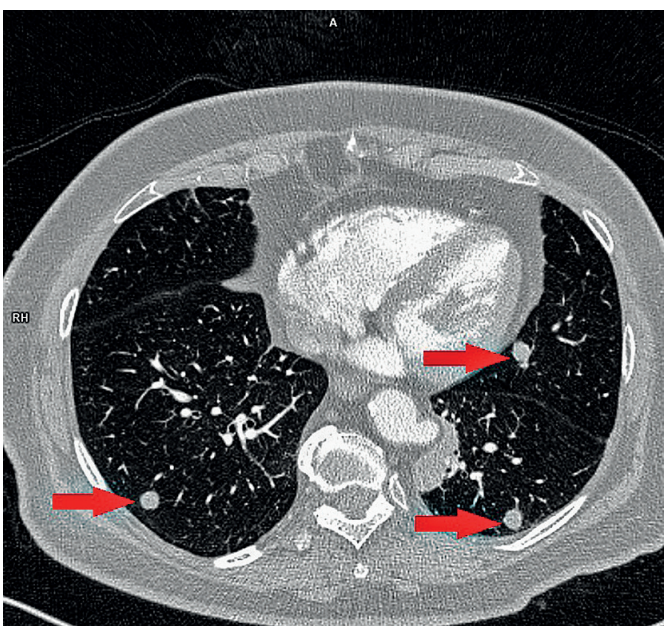

FIGURE 1. CT scan of the chest shows lung metastases in both lungs

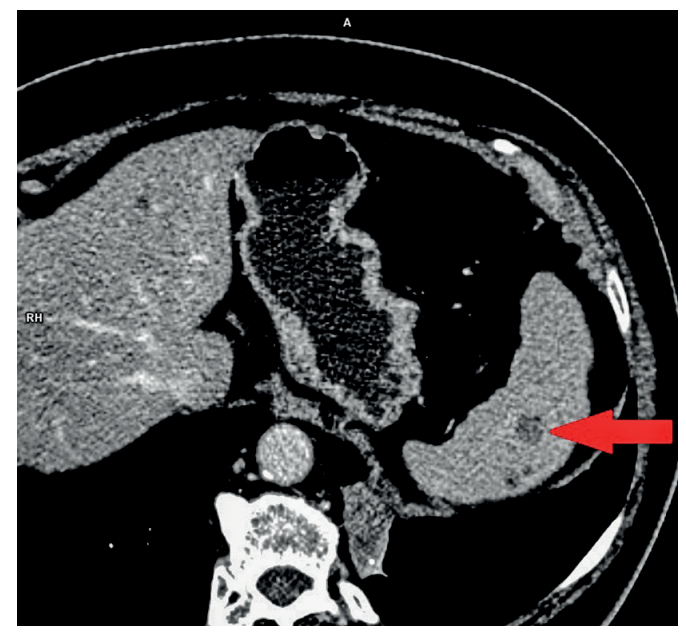

FIGURE 2. Abdominal CT shows metastases in the spleen

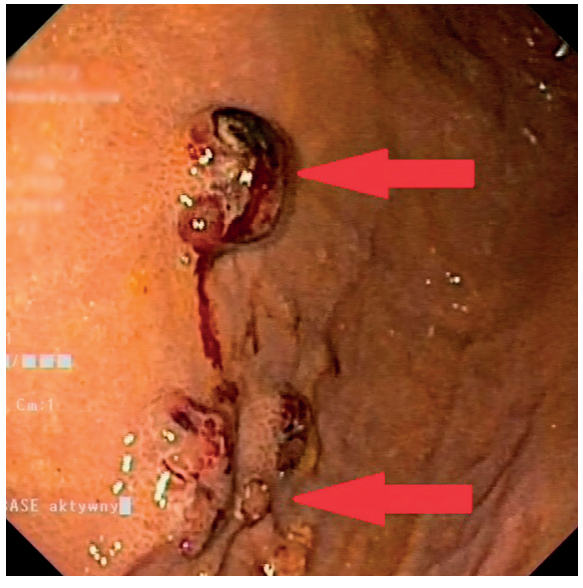

FIGURE 3. Melanotic and amelanotic metastatic lesions in the gastric body

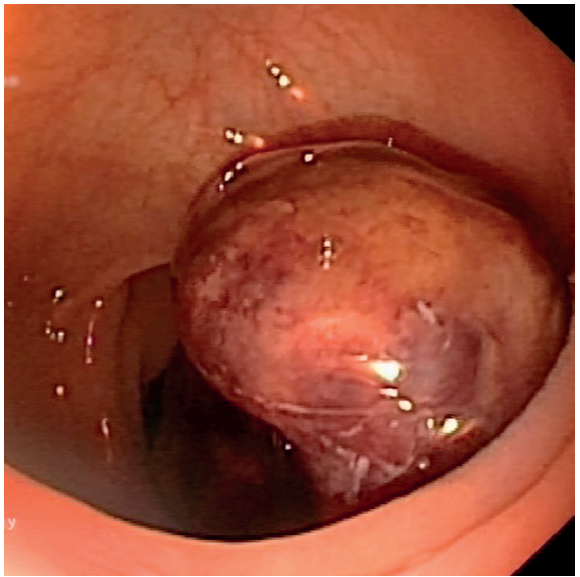

FIGURE 4. Colonoscopy. One of the bulging tumor-like lesion in large intestine

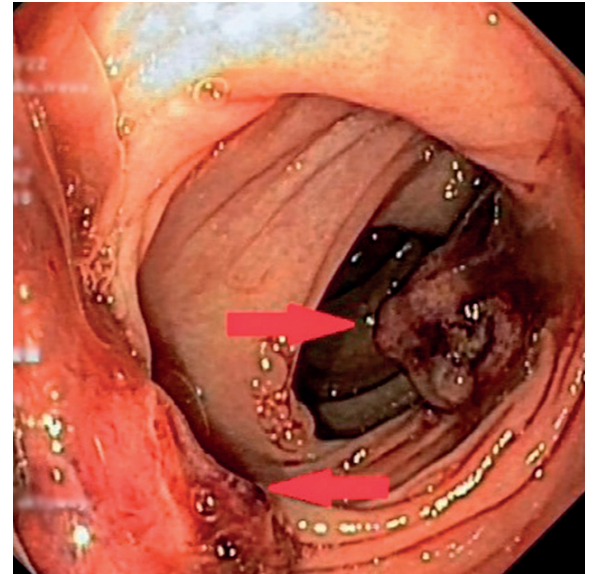

FIGURE 5. Colonoscopy. Multiple metastatic lesions in large intestine

\section{DISCUSSION}

Gastrointestinal (GI) melanoma metastases are present in up to $60 \%$ of patients with advanced melanoma, while locating primary lesions is a rare occurrence $[1,2]$. Most metastases are detected in autopsy studies, with only $5 \%$ found during the patient's lifetime [2]. Delays in diagnosis are related to the prevalence of either asymptomatic course or non-specific symptoms like weight-loss, chronic abdominal pain, anemia, or weakness. Furthermore, GI emergency symptoms like bleeding, bowel obstruction, intussusception, or perforation are rare $[1,3]$. Every part of the GI tract can be involved; however, the most frequent site of metastatic spreading is the small intestine $[1,2]$. Imaging studies and endoscopy show infiltrating, polypoid, ulcerative, subepithelial, tumor-like (resembling cancer or lymphoma) lesions, that can be either pigmented or amelanotic $[3,4,5]$. The treatment for secondary GI melanoma is either surgery, chemo- or immunotherapy [3]. In case of single bleeding lesions, standard hemostatic endoscopic techniques can be used [5]. In this case, we decided against the use of these methods, taking into consideration the extent and multiplicity of the clot-covered lesions. There are data showing that surgery leads to good palliation and can even improve survival [2]. However, the prognosis for metastic melanoma, even with surgery, is still poor, with a mean 1-year survival of $30 \%$ and 5 -year survival of $20 \%$ [2].

\section{CONCLUSIONS}

We decided to present the case of this patient to underline the problem of secondary GI tract involvement in patients with melanoma. Metastatic spread with involvement of both stomach and colon is rarely diagnosed in intravital studies and metastases to the spleen are generally infrequent. It should be remembered that metastases to the GI tract can resemble other polypoid lesions and can be misdiagnosed macroscopically (especially amelanotic metastatic lesions) 
as benign findings. In cases of patients with history of melanoma, metastases should be considered as the cause of nonspecific abdominal symptoms, anemia, or bleeding from the gastrointestinal tract.

\section{REFERENCES}

1. Galanopoulos M, Gkeros F, Liatsos C, Pontas C, Papaefthymiou A, Viazis $\mathrm{N}$, et al. Secondary metastatic lesions to colon and rectum. Ann Gastroenterol 2018;31(3):282-7.
2. Park JS, Ng KS, Saw RPM, Thompson JF, Young CJ. Metastatic melanoma to the colon, rectum, and anus: A 50-Year Experience. Ann Surg Oncol 2018;25(8):2178-83.

3. Genova P, Sorce M, Cabibi D, Genova G, Gebbia V, Galanti D, et al. Gastric and rectal metastases from malignant melanoma presenting with hypochromic anemia and treated with immunotherapy. Case Rep Oncol Med 2017;2017:1-4.

4. Trouillet N, Robert B, Charfi S, Bartoli E, Joly JP, Chatelain D. Gastric metastases. An endoscopic series of ten cases. Gastroenterol Clin Biol 2010;34(4-5):305-9.

5. Falk V, Zepeda-Gomez S, Sultanian R, Kohansal-Vajargah A. Acute upper gastrointestinal bleeding in a patient with malignant melanoma. BMJ Case Rep 2018;2018:bcr-2018-225869. 